Int. J. Environ. Sci. Tech.

(C) Summer 2005, Vol. 2, No. 2, pp. 113-120

\title{
Growth and ionic relations of fodderbeet and seabeet under saline environments
}

\author{
${ }^{1}$ B. H. Niazi, ${ }^{2 *}$ M. Athar, ${ }^{1}$ M. Salim and ${ }^{3}$ J. Rozema \\ ${ }^{1}$ Institute of Natural Resources and Environmental Sciences, National Agricultural Research Center, Pakistan Agricultural \\ Research Council, Islamabad, Pakistan \\ ${ }^{2}$ California Department of Food and Agriculture, Sacramento, USA \\ ${ }^{3}$ Department of Ecotoxicology, Free University, Amsterdam, Netherlands
}

\begin{abstract}
Growth and ionic relations of fodderbeet (Beta vulgaris) and seabeet (B.maritima) were studied in a greenhouse experiment using garden soil salinized with $200 \mathrm{mM} \mathrm{NaCl}$. Both the species tolerated salinity level of $200 \mathrm{mM} \mathrm{NaCl}$, but seabeet performed better than fodderbeet. Fresh weight of shoot increased significantly $(\mathrm{P}<0.01)$ under higher salt concentration in both the species. Fodderbeet accumulated more biomass under saline conditions than seabeet. Salt treated plants accumulated significantly higher $\mathrm{Na}^{+}$and $\mathrm{Cl}^{-}$content in shoot compared to untreated control plants. Chloride ( $\mathrm{Cl}$ ) of seabeet root was significantly higher than shoot; however, chloride content of shoot was significantly lower in fodderbeet. The concentration of these ions was comparatively higher in seabeet root than fodderbeet in the later growth period. Potassium $\mathrm{K}^{+}$content was low and revealed antagonistic effect with that of $\mathrm{Na}^{+}$content. Calcium $\left(\mathrm{Ca}^{+2}\right)$ ions were not significantly absorbed by shoot of both species. A significant effect of treatment by the root has been observed in both species. Magnesium $\left(\mathrm{Mg}^{+2}\right)$ content of shoot were increased with the time. Seabeet has absorbed more $\mathrm{Mg}^{+2}$ than fodderbeet. The fodderbeet showed a significant salt tolerance during five week growth period. Seabeet is comparatively more salt tolerant. Domesticated cultivars of fodderbeet like Majoral have considerable adaptability in the inland salt affected areas of Pakistan.
\end{abstract}

Key words: Sodium chloride, potassium, relative growth rate, fodderbeet, sugarbeet, saline environment

*Corresponding Author, E-mail: atariq@cdfa.ca.gov

\section{Introduction}

Salinity is a limiting factor to crop production. Yields of most crops are decreased when cultivated in salt affected areas. Generally salinity problems are handled by chemical and biological methods. Chemical methods are usually used to reclaim sodic soils (Qadir, et al., 2000). While cultivation of salt tolerant species on salt-affected lands forms the basis of the biological reclamation. Identification of a wide variety of species with higher salt tolerance is important to achieve more success from this approach. Fodderbeet, is highly salt tolerant during vegetative growth (Niazi, et al., 2000). The sugarbeet and fodderbeet yield is improved by application of sodium chloride as fertilizer (Draycott and Durrant, 1976; Magat and Goh, 1988). This improvement has been related to the increase in root sugar yield with enhanced uptake of $\mathrm{Na}^{+}$from soil (Hamid and Talibudeen, 1976). Chloride is a essential nutrient for plants (Marschner, 1986). Cell wall extensibility is significantly affected by deposition of $\mathrm{Ca}^{2+}$ in the cell wall, either by forming cross bridges or by inhibiting wall loosening enzymes (Cleland, 1986). The concentration of $\mathrm{Ca}^{2+}$ and $\mathrm{Mg}^{2+}$ in reclaimed soils was reported to be higher at the top (Qadir, et al., 2000 and 2001). Maximum $\mathrm{Ca}^{2+}$ uptake by the plant from these soils can affect the plant growth. Magnesium is an important component of chlorophyll (Marschner, 1986) and presence of magnesium in plant can indirectly improve the growth of plant by more chlorophyll synthesis and better rate of photosynthesis in plant. Although the halophilous nature has been reported in literature (Magat and Goh, 1988), there is a little information about the role of various ions in the growth of fodderbeet. These factors point towards the importance of various ions for the optimum growth of the plant tissue. Fodderbeet and seabeet are the chenopod mainly grown as supplementary stock feed in coastal areas in winter when there is an acute shortage of fodder for the livestock in Pakistan. A series of experiments are underway in our unit to explore the possibilities of improving growth and 
production of these plants under moderately salinesodic soil conditions (Niazi, et al., 1999, 2000, 2002, 2004a and 2004b). The present study constitutes the results of an experiment conducted to determine the growth response and ionic relations of the fodderbeet and seabeet grown in salinized garden soil in the greenhouse. The resaerch was conducted at National Agricultural Research Center, PARC, Islamabad, Pakistan during 2003.

\section{Materials and Methods}

Seeds of two species of fodderbeet (Beta vulgaris cv. Majoral) and seabeet (Beta maritima) were germinated in sand under greenhouse conditions (temperature: 30, EC: 25 in day/ night, relative humidity $70 \%$, light: $250 \mathrm{mE} \mathrm{m}^{-2} \mathrm{~s}^{-1}$ ). Ten days old seedlings were transplanted to pots (one seedling per pot) kept in greenhouse filled with one kg garden soil (Potgrond mengselm, Aalsmeer). Physico-chemical characteristics of the soil are provided elsewhere (Niazi, et al., 2004a). Two treatment levels ( $0 \mathrm{mM} \mathrm{NaCl}$; (control), and 200 $\mathrm{mM} \mathrm{NaCl}$ ) were maintained in the pots. Salinity was increased stepwise by addition of $50 \mathrm{mM} \mathrm{NaCl}$ every two days (twice added on the top of soil and later, to plate placed at the base of pot to keep salinity uniform throughout the soil profile) one week after seedling establishment. There were 20 replications per salinity level. First harvest was done after seven days of maintaining the salinity level in the pots and the subsequent harvests were done with an interval of seven days between each harvest.

Plant material was dried at $60{ }^{\circ} \mathrm{C}$ in an oven to a constant weight and was analyzed for cations ( $\mathrm{Na}$, $\mathrm{K}$, Ca, Mg) using Atomic Absorption Spectrophotometer (Perkin Elmer 2100, USA). Chloride content was measured by Chloro-counter by the method instructed in the instrument operating manual (Marius Instrumenten, Utrecht, The Netherlands). The data were statistically analyzed using three way ANOVA methods described by Sokal and Rohlf (1981). Means were compared with the LSD multiple mean comparison test at significance levels at $\mathrm{P}<0.01$.

\section{Results}

\section{Biomass production}

Fresh weight of shoot increased significantly $(\mathrm{P}<$ 0.01) under higher salt concentration in both the species. Fodderbeet accumulated more biomass under saline conditions than seabeet. Dry matter accumulation of the shoot increased with the age of the plant and the presence of salt enhanced the dry matter production (Table 1). Fresh weight of root did not increase significantly $(\mathrm{P}<0.01)$ for the first 21 days. It increased significantly in the later period under study. There was a significant $(\mathrm{P}<0.01)$ difference in the fresh weight of species. Salt treatment has no effect on fresh weight. Dry matter yield of root significantly decreased in fodderbeet under saline conditions. However, no significant effect on the dry matter yield of root was observed under higher salt treatment (Table 2).

\section{Ion concentration}

The concentration of $\mathrm{Na}^{+}$in plants significantly $(\mathrm{P}<0.01)$ increased in the presence of $200 \mathrm{mM} \mathrm{NaCl}$ in the root medium. The concentration of $\mathrm{Na}^{+}$ increased with time in control plants $(0 \mathrm{mM} \mathrm{NaCl})$ as well. In general, shoot had higher Na content than root (Table 3). $\mathrm{Na}^{+}$content in root increased with time irrespective of treatment. Fodderbeet had absorbed higher $\mathrm{Na}^{+}$than seabeet. Effect of high $\mathrm{NaCl}$ concentation in growth medium resulted in significantly $(\mathrm{P}<0.01)$ higher $\mathrm{Cl}^{-}$in seabeet root which had higher $\mathrm{Cl}^{-}$than shoot (Table 4). Chloride content in both the shoot and root increased with time. Potassium content of plant generally decreased under saline conditions. Shoot absorbed significantly $(\mathrm{P}<0.01)$ higher $\mathrm{K}^{+}$content than root (Table 5). Potassium ion concentration decreased with time both in shoot and root. Uptake of $\mathrm{K}^{+}$by root and shoot was significantly $(\mathrm{P}<0.01)$ low under saline conditions in seabeet than fodderbeet. Plant growth showed a significant correlation $(r=-0.72)$ with $K$ ion uptake by the plant which is a useful trend in the plants grown under saline environments. Uptake of calcium was enhanced by the presence of salt (200 $\mathrm{mM} \mathrm{NaCl}$ ) during early growth period in root (Table 6). Calcium ion $\left(\mathrm{Ca}^{+2}\right)$ content was significantly $(\mathrm{P}<$ 0.01) higher in seabeet root than fodderbeet during first week of growth. Calcium content significantly increased in fodderbeet shoot with the age of the plant. There was significant $(\mathrm{P}<0.01)$ difference in $\mathrm{Ca}^{+2}$ content of seabeet shoot under saline conditions, at the age of 28-35 days. Calcium ion $\left(\mathrm{Ca}^{+2}\right)$ content of seabeet shoot were increased in the control plants. Magnesium content in fodderbeet shoot decreased under saline conditions. However, $\mathrm{Mg}^{+2}$ content significantly decreased in fodderbeet root and shoot during 28-35 days in the presence of $200 \mathrm{mM} \mathrm{NaCl}$ (Table 7). Magnesium content in seabeet shoot 
Table 1: Biomass production ( $\mathrm{g} \mathrm{g}^{-1}$ dry weight) in fodderbeet and seabeet at different time intervals exposed to higher salinity level

\begin{tabular}{|c|c|c|c|c|c|c|c|}
\hline \multicolumn{8}{|c|}{ Fresh weight } \\
\hline \multirow{2}{*}{ Plant } & \multirow{2}{*}{$\begin{array}{c}\text { Treatment } \\
\mathrm{NaCl}(\mathrm{mM})\end{array}$} & \multicolumn{4}{|c|}{ Harvest (days) } & \multirow[b]{2}{*}{35} & \multirow{2}{*}{ Mean } \\
\hline & & 7 & 14 & 21 & 28 & & \\
\hline \multirow{2}{*}{ Fodderbeet } & 0 & 2.708 & 13.849 & 21.695 & 25.279 & 27.014 & 18.110 \\
\hline & 200 & 2.683 & 11.314 & 30.638 & 42.252 & 44.787 & 26.340 \\
\hline \multirow{2}{*}{ Seabeet } & 0 & 0.723 & 4.806 & 6.636 & 10.680 & 13.495 & 7.268 \\
\hline & 200 & 0.480 & 2.660 & 11.270 & 25.098 & 27.260 & 13.354 \\
\hline \multicolumn{2}{|c|}{ Mean } & 1.649 & 8.157 & 17.56 & 25.827 & 28.14 & \\
\hline
\end{tabular}

\begin{tabular}{|c|c|c|c|c|c|c|c|}
\hline \multicolumn{8}{|c|}{ Dry weight } \\
\hline \multirow{2}{*}{ Plant } & \multirow{2}{*}{$\begin{array}{l}\text { Treatment } \\
\mathrm{NaCl}(\mathrm{mM})\end{array}$} & \multicolumn{4}{|c|}{ Harvest (days) } & \multirow[b]{2}{*}{35} & \multirow{2}{*}{ Mean } \\
\hline & & 7 & 14 & 21 & 28 & & \\
\hline \multirow{2}{*}{ Fodderbeet } & 0 & 0.112 & 0.565 & 1.312 & 3.213 & 3.047 & 1.650 \\
\hline & 200 & 0.122 & 0.536 & 1.523 & 3.087 & 4.443 & 1.942 \\
\hline \multirow{2}{*}{ Seabeet } & 0 & 0.042 & 0.259 & 0.533 & 1.007 & 1.641 & 0.696 \\
\hline & 200 & 0.029 & 0.167 & 0.633 & 2.465 & 2.475 & 1.160 \\
\hline \multicolumn{2}{|c|}{ Mean } & 0.076 & 0.382 & 1.008 & 2.443 & 2.901 & \\
\hline
\end{tabular}

Table 2: Root weight ( $\mathrm{g} \mathrm{g}^{-1}$ dry weight) of fodderbeet and seabeet at different time intervals exposed to higher salinity level

\begin{tabular}{|c|c|c|c|c|c|c|c|}
\hline \multirow{3}{*}{ Plant } & \multicolumn{7}{|c|}{ Fresh weight } \\
\hline & \multirow{2}{*}{$\begin{array}{l}\text { Treatment } \\
\mathrm{NaCl}(\mathrm{mM})\end{array}$} & \multicolumn{5}{|c|}{ Harvest (days) } & \multirow{2}{*}{ Mean } \\
\hline & & 7 & 14 & 21 & 28 & 35 & \\
\hline \multirow{2}{*}{ Fodderbeet } & 0 & 0.395 & 2.958 & 7.272 & 17.080 & 21.573 & 9.856 \\
\hline & 200 & 0.454 & 2.319 & 6.896 & 16.211 & 37.133 & 12.602 \\
\hline \multirow[t]{2}{*}{ Seabeet } & 0 & 0.156 & 0.848 & 2.363 & 4.710 & 12.472 & 4.110 \\
\hline & 200 & 0.197 & 0.827 & 1.791 & 6.447 & 10.172 & 3.887 \\
\hline \multicolumn{2}{|c|}{ Mean } & 0.300 & 1.738 & 4.581 & 11.112 & 20.337 & \\
\hline
\end{tabular}

\begin{tabular}{|c|c|c|c|c|c|c|c|}
\hline \multirow{3}{*}{ Plant } & \multicolumn{7}{|c|}{ Dry weight } \\
\hline & \multirow{2}{*}{$\begin{array}{c}\text { Treatment } \\
\mathrm{NaCl}(\mathrm{mM})\end{array}$} & \multicolumn{5}{|c|}{ Harvest (days) } & \multirow{2}{*}{ Mean } \\
\hline & & 7 & 14 & 21 & 28 & 35 & \\
\hline \multirow{2}{*}{ Fodderbeet } & 0 & 0.030 & 0.205 & 0.873 & 2.486 & 4.058 & 1.530 \\
\hline & 200 & 0.037 & 0.159 & 0.572 & 2.422 & 0.493 & 0.737 \\
\hline \multirow{2}{*}{ Seabeet } & 0 & 0.017 & 0.080 & 0.356 & 0.828 & 2.492 & 0.755 \\
\hline & 200 & 0.021 & 0.079 & 0.214 & 0.910 & 1.946 & 0.634 \\
\hline \multicolumn{2}{|c|}{ Mean } & 0.027 & 0.131 & 0.503 & 1.662 & 2.247 & \\
\hline
\end{tabular}


Table 3: Sodium content (mg g-1 dry weight) in shoot and root of fodderbeet and seabeet at different time intervals exposed to higher salinity level

\begin{tabular}{|c|c|c|c|c|c|c|c|}
\hline \multirow{3}{*}{ Plant } & \multicolumn{6}{|c|}{ Shoot } & \multirow{3}{*}{ Mean } \\
\hline & \multicolumn{2}{|l|}{ Treatment } & \multicolumn{3}{|c|}{ Harvest (days) } & \multirow[b]{2}{*}{35} & \\
\hline & $\mathrm{NaCl}(\mathrm{mM})$ & 7 & 14 & 21 & 28 & & \\
\hline \multirow{2}{*}{ Fodderbeet } & 0 & 8.650 & 8.990 & 9.820 & 9.910 & 11.090 & 9.69 \\
\hline & 200 & 19.660 & 24.886 & 26.750 & 25.910 & 28.520 & 25.14 \\
\hline \multirow{2}{*}{ Seabeet } & 0 & 9.540 & 9.940 & 10.740 & 11.060 & 11.520 & 10.58 \\
\hline & 200 & 17.990 & 18.720 & 19.490 & 21.110 & 22.510 & 19.64 \\
\hline \multicolumn{2}{|c|}{ Mean } & 13.96 & 15.63 & 16.70 & 17.00 & 18.410 & \\
\hline
\end{tabular}

\begin{tabular}{|c|c|c|c|c|c|c|c|}
\hline \multirow{3}{*}{ Plant } & \multicolumn{6}{|c|}{ Root } & \multirow{3}{*}{ Mean } \\
\hline & \multicolumn{2}{|l|}{ Treatment } & \multicolumn{3}{|c|}{ Harvest (days) } & \multirow[b]{2}{*}{35} & \\
\hline & $\mathrm{NaCl}(\mathrm{mM})$ & 7 & 14 & 21 & 28 & & \\
\hline \multirow[t]{2}{*}{ Fodderbeet } & 0 & 2.810 & 3.010 & 3.360 & 3.470 & 4.350 & 3.40 \\
\hline & 200 & 13.070 & 13.400 & 13.880 & 14.540 & 15.430 & 14.06 \\
\hline \multirow[t]{2}{*}{ Seabeet } & 0 & 3.290 & 3.470 & 3.770 & 3.960 & 3.890 & 3.68 \\
\hline & 200 & 9.860 & 12.290 & 14.920 & 17.520 & 24.050 & 15.73 \\
\hline \multicolumn{2}{|c|}{ Mean } & 7.26 & 8.040 & 8.98 & 9.87 & 11.930 & \\
\hline
\end{tabular}

Table 4: Chloride content (mg g ${ }^{-1}$ dry weight) in shoot and root of fodderbeet and seabeet at different time intervals exposed to higher salinity level

\begin{tabular}{|c|c|c|c|c|c|c|c|}
\hline \multirow{3}{*}{ Plant } & \multicolumn{6}{|c|}{ Shoot } & \multirow{3}{*}{ Mean } \\
\hline & \multicolumn{2}{|l|}{ Treatment } & \multicolumn{2}{|c|}{ Harvest (days) } & & \multirow[b]{2}{*}{35} & \\
\hline & $\mathrm{NaCl}(\mathrm{mM})$ & 7 & 14 & 21 & 28 & & \\
\hline \multirow{2}{*}{ Fodderbeet } & 0 & 5.640 & 1.680 & 2.690 & 2.690 & 3.010 & 3.14 \\
\hline & 200 & 35.770 & 43.290 & 44.390 & 52.330 & 67.350 & 48.63 \\
\hline \multirow{2}{*}{ Seabeet } & 0 & 1.960 & 2.210 & 2.450 & 2.840 & 3.050 & 2.50 \\
\hline & 200 & 21.460 & 23.230 & 23.680 & 27.040 & 43.890 & 27.86 \\
\hline \multicolumn{2}{|c|}{ Mean } & 16.21 & 17.60 & 18.30 & 21.26 & 29.33 & \\
\hline
\end{tabular}

\begin{tabular}{|c|c|c|c|c|c|c|c|}
\hline \multicolumn{8}{|c|}{ Root } \\
\hline \multirow{2}{*}{ Plant } & \multirow{2}{*}{$\begin{array}{c}\text { Treatment } \\
\mathrm{NaCl}(\mathrm{mM})\end{array}$} & \multicolumn{5}{|c|}{ Harvest (days) } & \multirow{2}{*}{ Mean } \\
\hline & & 7 & 14 & 21 & 28 & 35 & \\
\hline \multirow{2}{*}{ Fodderbeet } & 0 & 2.450 & 3.220 & 3.540 & 3.640 & 4.100 & 3.43 \\
\hline & 200 & 27.150 & 28.470 & 33.240 & 36.040 & 42.140 & 33.41 \\
\hline \multirow{2}{*}{ Seabeet } & 0 & 1.470 & 2.590 & 2.520 & 4.100 & 4.340 & 3.00 \\
\hline & 200 & 66.070 & 70.390 & 85.820 & 96.740 & 114.760 & 91.96 \\
\hline \multicolumn{2}{|c|}{ Mean } & 24.29 & 26.17 & 31.28 & 35.13 & & \\
\hline
\end{tabular}


Table 5: Potassium content (mg g ${ }^{-1}$ dry weight) in shoot and root of fodderbeet and seabeet at different time intervals exposed to higher salinity level

\begin{tabular}{|c|c|c|c|c|c|c|c|}
\hline \multirow{3}{*}{ Plant } & \multicolumn{6}{|c|}{ Shoot } & \multirow{3}{*}{ Mean } \\
\hline & \multirow{2}{*}{$\frac{\text { Treatment }}{\mathrm{NaCl}(\mathrm{mM})}$} & \multicolumn{5}{|c|}{ Harvest (days) } & \\
\hline & & 7 & 14 & 21 & 28 & 35 & \\
\hline \multirow{2}{*}{ Fodderbeet } & 0 & 1.400 & 1.370 & 0.980 & 0.820 & 0.740 & 1.06 \\
\hline & 200 & 1.260 & 1.200 & 0.590 & 0.710 & 0.620 & 0.88 \\
\hline \multirow{2}{*}{ Seabeet } & 0 & 1.450 & 1.300 & 1.120 & 1.090 & 0.930 & 1.18 \\
\hline & 200 & 1.280 & 1.270 & 1.230 & 1.090 & 0.990 & 1.17 \\
\hline \multicolumn{2}{|c|}{ Mean } & 1.35 & 1.29 & 0.98 & 0.93 & 0.82 & \\
\hline
\end{tabular}

\begin{tabular}{|c|c|c|c|c|c|c|c|}
\hline \multicolumn{8}{|c|}{ Root } \\
\hline \multirow{2}{*}{ Plant } & Treatment & \multicolumn{5}{|c|}{ Harvest (days) } & \multirow{2}{*}{ Mean } \\
\hline & $\mathrm{NaCl}(\mathrm{mM})$ & 7 & 14 & 21 & 28 & 35 & \\
\hline \multirow{2}{*}{ Fodderbeet } & 0 & 0.960 & 0.830 & 0.780 & 0.600 & 0.450 & 0.72 \\
\hline & 200 & 0.630 & 0.490 & 0.420 & 0.360 & 0.310 & 0.44 \\
\hline \multirow{2}{*}{ Seabeet } & 0 & 1.040 & 0.950 & 0.670 & 0.610 & 0.540 & 0.76 \\
\hline & 200 & 0.520 & 0.480 & 0.440 & 0.370 & 0.330 & 0.43 \\
\hline \multicolumn{2}{|c|}{ Mean } & 0.79 & 0.69 & 0.58 & 0.49 & 0.41 & \\
\hline
\end{tabular}

Table 6: Calcium content (mg g ${ }^{-1}$ dry weight) in shoot and root of fodderbeet and seabeet at different time intervals exposed to higher salinity level

\begin{tabular}{|c|c|c|c|c|c|c|c|}
\hline \multicolumn{8}{|c|}{ Shoot } \\
\hline \multirow{2}{*}{ Plant } & \multicolumn{3}{|l|}{ Treatment } & \multicolumn{3}{|c|}{ Harvest (days) } & \multirow{2}{*}{ Mean } \\
\hline & $\mathrm{NaCl}(\mathrm{mM})$ & 7 & 14 & 21 & 28 & 35 & \\
\hline \multirow[t]{2}{*}{ Fodderbeet } & 0 & 0.030 & 0.040 & 0.050 & 0.060 & 0.080 & 0.05 \\
\hline & 200 & 0.050 & 0.060 & 0.060 & 0.090 & 0.07 & 0.06 \\
\hline \multirow{2}{*}{ Seabeet } & 0 & 0.050 & 0.070 & 0.080 & 0.080 & 0.08 & 0.07 \\
\hline & 200 & 0.070 & 0.080 & 0.080 & 0.090 & 0.100 & 0.08 \\
\hline \multicolumn{2}{|c|}{ Mean } & 0.05 & 0.06 & 0.07 & 0.08 & 0.07 & \\
\hline
\end{tabular}

\begin{tabular}{|c|c|c|c|c|c|c|c|}
\hline \multicolumn{8}{|c|}{ Root } \\
\hline \multirow{2}{*}{ Plant } & Treatment & \multicolumn{5}{|c|}{ Harvest (days) } & \multirow{2}{*}{ Mean } \\
\hline & $\mathrm{NaCl}(\mathrm{mM})$ & 7 & 14 & 21 & 28 & 35 & \\
\hline \multirow{2}{*}{ Fodderbeet } & 0 & 0.110 & 0.280 & 0.220 & 0.310 & 0.300 & 0.22 \\
\hline & 200 & 0.280 & 0.190 & 0.280 & 0.230 & 0.210 & 0.26 \\
\hline \multirow{2}{*}{ Seabeet } & 0 & 0.270 & 0.280 & 0.190 & 0.180 & 0.170 & 0.20 \\
\hline & 200 & 0.350 & 0.350 & 0.280 & 0.200 & 0.200 & 0.28 \\
\hline \multicolumn{2}{|c|}{ Mean } & 0.25 & 0.25 & 0.24 & 0.23 & 0.22 & \\
\hline
\end{tabular}


Table 7: Magnesium content (mg g-1 dry weight) in shoot and root of fodderbeet and seabeet at different time intervals exposed to higher salinity level

\begin{tabular}{|c|c|c|c|c|c|c|c|}
\hline \multicolumn{8}{|c|}{ Shoot } \\
\hline \multirow{2}{*}{ Plant } & \multicolumn{2}{|l|}{ Treatment } & \multicolumn{3}{|c|}{ Harvest (days) } & \multirow[b]{2}{*}{35} & \multirow{2}{*}{ Mean } \\
\hline & $\mathrm{NaCl}(\mathrm{mM})$ & 7 & 14 & 21 & 28 & & \\
\hline \multirow{2}{*}{ Fodderbeet } & 0 & 2.000 & 2.010 & 2.040 & 2.020 & 2.050 & 2.02 \\
\hline & 200 & 1.210 & 1.480 & 2.100 & 2.110 & 2.130 & 1.85 \\
\hline \multirow{2}{*}{ Seabeet } & 0 & 1.860 & 1.930 & 1.940 & 2.000 & 2.010 & 1.95 \\
\hline & 200 & 2.030 & 2.090 & 2.150 & 2.670 & 2.700 & 2.33 \\
\hline \multicolumn{2}{|c|}{ Mean } & 1.82 & 1.88 & 2.05 & 2.20 & 2.22 & \\
\hline
\end{tabular}

\begin{tabular}{|c|c|c|c|c|c|c|c|}
\hline \multicolumn{8}{|c|}{ Root } \\
\hline \multirow{2}{*}{ Plant } & Treatment & \multicolumn{5}{|c|}{ Harvest (days) } & \multirow{2}{*}{ Mear } \\
\hline & $\mathrm{NaCl}(\mathrm{mM})$ & 7 & 14 & 21 & 28 & 35 & \\
\hline \multirow{2}{*}{ Fodderbeet } & 0 & 0.970 & 0.940 & 0.940 & 0.870 & 0.870 & 0.92 \\
\hline & 200 & 0.910 & 0.870 & 0.860 & 0.820 & 0.800 & 0.85 \\
\hline \multirow{2}{*}{ Seabeet } & 0 & 1.100 & 1.380 & 1.170 & 1.240 & 1.260 & 1.23 \\
\hline & 200 & 1.370 & 1.440 & 1.490 & 1.540 & 1.700 & 1.51 \\
\hline \multicolumn{2}{|c|}{ Mean } & 1.09 & 1.16 & 1.12 & 1.12 & 1.16 & \\
\hline
\end{tabular}

\section{Discussion and Conclusion}

The presence of $\mathrm{NaCl}$ in growth medium had enhanced the uptake of $\mathrm{Na}^{+}$by the plant. Control ( 0 $\mathrm{mM} \mathrm{NaCl}$ ) plants also absorbed available sodium. The concentration of $\mathrm{Na}^{+}$seemed not very high with plant growth due to rapid division and growth of cells and distribution of $\mathrm{Na}^{+}$ions within the cells which caused dilution of ion concentration (Grieve and Fujiyama, 1987). Plant absorbed more $\mathrm{Na}^{+}$under saline conditions from the growth medium than control, thus $\mathrm{Na}^{+}$concentration of the plant tissue increased during growth until final harvest. Translocation of ions from root to shoot in the presence of saline environment was comparatively higher than the control. Uptake of water by the root caused a regular addition of $\mathrm{Na}^{+}$from growth medium. Sodium ion concentration of root was probably low to interact with potassium absorption for the first two weeks. A significantly different $\mathrm{Na}^{+}$accumulation in rice shoot under saline conditions have been described by Flowers and Yeo (1981). Grieve and Fujiyama (1987) noted a 35-40\% standard deviation in data related to $\mathrm{Na}^{+}$ concentration in rice cultivars. This variation was related to shoot growth rather than a reduction of net sodium uptake. High $\mathrm{Na}^{+}$and $\mathrm{Cl}^{-}$ion accumulation by Beta spp. confirm the family Chenopodiaceae as salt accumulators (Rozema, et al., 1981). Presence of higher $\mathrm{NaCl}$ treatments increased $\mathrm{Cl}^{-}$ ion accumulation in the root upto the third week. The chloride ion further increased in seabeet until final harvest in the presence of high $\mathrm{NaCl}$ concentration. Addition of $\mathrm{NaCl}$ to growth medium is followed by increase in $\mathrm{pH}$ (probably due to $\mathrm{Cl}^{-}$). Chloride concentration increases in shoot with high $\mathrm{pH}$, while root is little affected (Findenegg, et al., 1989). This condition is hazardous for plant growing under saline soil because of high $\mathrm{pH}$, which will favour $\mathrm{Cl}$ concentration in plant and cause reduction in growth. Increase of $\mathrm{Cl}$ in shoot is favored by significant transportation of $\mathrm{Cl}$ to shoot. A highly significant correlation (fodderbeet $\mathrm{r}=0.93$; seabeet $\mathrm{r}=0.97$ ) between $\mathrm{Na}^{+}$and $\mathrm{Cl}^{-}$ions has been recorded in shoot and root of both the species studied. Salinity induced growth reduction in seabeet was comparatively lower (Niazi et al., 1999) which is an indication of its high salt tolerance which may be related to low chloride concentration in shoot of seabeet compared to that of fodderbeet. The concentration of $\mathrm{K}^{+}$in seabeet root significantly $(\mathrm{P}<$ 0.01 ) decreased under saline conditions. This may be related to antagonistic effect of $\mathrm{K}^{+}$with $\mathrm{Na}^{+}$ seabeet has comparatively lower $\mathrm{Na}^{+}$content in shoot than fodderbeet and $\mathrm{K}^{+}$increase in shoot may 
be due to antagonistic effect with sodium under saline conditions (Plaut and Grieve, 1988).

significantly $(\mathrm{P}<0.01)$ increased after 7-35 days in the presence of $200 \mathrm{mM} \mathrm{NaCl}$.

A negative correlation $(\mathrm{r}=-0.77)$ has been observed in $\mathrm{Na}$ shoot/K root in fodderbeet while the seabeet has shown a higher correlation value $(\mathrm{r}=-0.88)$. Niazi and Ahmad (1984) in tomato and Ashraf, et al. (2003) in okra have also confirmed antagonistic effect of $\mathrm{Na}^{+}$and $\mathrm{K}^{+}$ion during a study on the uptake of ions in under saline soil conditions. Some graminaceous species growing in nutrient cultures containing $\mathrm{NaCl}$ as a sole osmoticum, frequently displayed leaf blade deformation and necrosis that are characteristics of severe Cadeficiency. The physiological role of $\mathrm{Ca}^{+2}$ in the cellular system is to stabilize the cell wall structure to maintain membrane integrity, selectivity and to regulate selectivity of ion transport process (Hanson 1983). Membrane permeability may increase by $\mathrm{Na}^{+}$ displaced $\mathrm{Ca}^{+2}$ ions that are associated with the external surface of plasma lemma (Cramer, et al., 1985). In the present study a significant increase in $\mathrm{Ca}^{+2}$ concentration of root was observed in the presence of $\mathrm{NaCl}$, which may form part of a highly salt tolerant behavior of plant. Magnesium $\left(\mathrm{Mg}^{+2}\right)$ concentration was also not reduced with time in fodderbeet, and even in seabeet an increase in $\mathrm{Mg}^{+2}$ was observed at $200 \mathrm{mM} \mathrm{NaCl}$. The correlation of $\mathrm{Na}$ root/Mg shoot was significantly negative $(\mathrm{r}=$ -0.77 ) in fodderbeet, while this same correlation was highly positive $(r=0.91)$ in seabeet. Increase of $\mathrm{Ca}^{+2}$ in the leaf resulted in a marked reduction in leaf $\mathrm{Mg}^{+2}$. This Ca-Mg antagonism could lead to a disturbance in photosynthesis. Reduced photosynthesis was noted in maize due to $\mathrm{Mg}^{+2}$ deficiency (Peaslee and Moos, 1966). High $\mathrm{Ca}^{+2}$ in leaf may also interfere with $\mathrm{CO}_{2}$ fixation by inhibition of stroma enzymes specially those that are $\mathrm{Mg}$ activated (Charles and Halliwell, 1980). The present study proved no disturbance in Ca-Mg imbalance and $\mathrm{Mg}$ tended to increase with simultaneous increase in $\mathrm{Ca}^{+2}$ concentration. This resulted in better net photosynthesis of fodderbeet in the presence of high $\mathrm{NaCl}$ (Niazi, et al., 1999, 2004a and 2004b). The fodderbeet cv. Majoral tested showed a significant salt tolerance during first four week growth period under saline soil conditions. Salt tolerance is not a function of single organ or plant attribute, but it is the product of all the plant attributes (Ali, et al., 2004). Therefore a species exhibiting relative salt tolerance for all the plant attributes may be ideal one. Fodderbeet is halophilous in nature. Seabeet is especially highly tolerant because it grows in the coastal marshy places under natural conditions. The domesticated cultivarsof fodderbeet including cv. Majoral have been tested for adaptation in the inland areas of Pakistan (Niazi, et al., 1999). The better mechanism of salt tolerance may have been achieved by the plant through accumulation of more ions. The salt affected areas could be utilized by cultivation of these species to enhance the production of fodder for livestock as well as utilization of unproductive soils in the resource poor countries like Pakistan.

\section{Acknowledgments}

The financial assistance provided to first author by NUFFIC, The Netherlands, to complete this study is gratefully acknowledged. The first author is also indebted to the staff of the Department of Ecology and Ecotoxicology, Free University, Amsterdam, The Netherlands for technical help and cooperation during this study. The authors are thankful to Dr. Shoaib Ismail, International Center for Biosaline Agriculture, Dubai, UAE for valuable suggestions and helpful criticism on the manuscript. Appreciations are also extended to an anonymous reviewer at University of California, Davis, USA for critical comments that undoubtedly improved the quality of the paper. Authors are also grateful to Dr. Manzoor Qadir, Institut für Pflazenernährung, Giessen, Germany for providing many original reprints that helped in the preparation of this paper.

\section{References}

Ali, Y, Z. Islam, M.Y. Ashraf and G. R. Tahir, Effect of salinity on chlorophyll concentration, leaf area, yield and yield components of rice genotypes grown under saline environment. Int. J. Environ. Sci. Technol., 1 (3): 221-225, 2004

Ashraf, M., M. Irfan and A. Ahmad, Salt tolerance in okra: Ion relations and gas exchange characteristics. J. Plant Nutr., 26: 63-79, 2003

Charles, S. A. and B. Halliwel, Action of calcium ions on spinach (Spinacia oleracea) chloroplast fructose bisphosphatase and other enzymes of the calvin cycle. Biochem. J., 188: 775-779, 1980

Cleland, $R$. E., The role of hormones in wall loosening and plant growth. Aust. J. Plant Physiol,. 13: 93103, 1986

Cramer, G. R., A. Lauchli and V. S. Polito, Displacement 
of $\mathrm{Ca}^{+2}$ by $\mathrm{Na}^{+}$from the plasma lemma of root cells. Plant Physiol,. 79: 207-21, 1985

Draycott, A. P. and M. J. Durrant, Response by sugarbeet to potassium and sodium fertilizers, particularly in relation to soils containing little exchangeable potassium. J. Agric Sci.(Camb.)., 87: 105-112, 1976

Findenegg, G. R. and G. A. Nelemans and P. A. Arnozi, Effect of external $\mathrm{pH}$ and $\mathrm{Cl}^{-}$on the accumulation of $\mathrm{NH}_{4}$ ions in the leaves of sugarbeet. J. Plant Nutr., 12: 593-601, 1989

Flowers, T. J. and A.R. Yeo, Variability in the resistance of sodium chloride salinity within rice (Oryza sativa L.) varieties. New Phytol., 88: 363-373, 1986

Grieve, C. M. and H. Fujiyama, The response of two rice cultivars to external $\mathrm{Na} / \mathrm{Ca}$ ratio. Plant and Soil, 103:245-250, 1987

Hamid, A. and O. Talibudeen, Effects of sodium on the growth and ion uptake by barley, sugarbeet and broadbeans. J. Agric. Sci. (Camb.), 86: 49-56, 1976

Hanson, J. B., The role of calcium in plant growth. In:Current Topics in Plant Biochemistry and Physiology. D.D. Randall, D. G. Blevins and R. Larson (eds.), Univ. Missouri, Columbia, 1-24, 1983

Magat, S. S. and K. M. Goh, Effects of chloride fertilizers on yield and uptake of chloride, potassium and sodium by fodderbeet (Beta vulgaris L.) in two New Zealand soils. J. Agric. Sci. (Camb.), 111: 207-216, 1988

Marschner, H., Mineral Nutrition of Higher Plants. Academic Press, London, 1976

Niazi, B. H. and T. Ahmad, Effect of sodium chloride and zinc on the growth of tomato. II. Uptake of ions. Geobios, 11: 155-160, 1984

Niazi, B. H., M. Athar and J. Rozema, Salt tolerance in fodderbeet and seabeet: analysis of biochemical relations. Bulg. J. Plant Physiol., 29 (1-2):2004a
Niazi, B. H., J. Rozema and M. Athar, Effect of pregermination and post-germination treatment of growth hormones (kinetine and abscisic acid) on ion concentration and biochemical contents of fodderbeet and seabeet under saline soil conditions. Bulg. J. Plant Physiol., 29 (1-2): $2004 b$

Niazi, B. H., J. Rozema and M. Athar, Influence of farmyard manure application on fodderbeet production under saline sodic conditions. Bull. Polish. Acad. Sci., Series Biol. Sci., 50: 245-251, 2002

Niazi, B. H., J. Rozema, R. Amin, M. Salim and A. Rashid, Physiological characteristics of fodderbeet grown on saline sodic soils of Pakistan. Pak. J. Bio. Sci., 2: 595-598, 1999

Niazi, B. H., J. Rozema, R. A. Broekman and M. Salim, Dynamics of growth and water relations of fodderbeet and seabeet in response to salinity. J. Agron. Crop Sci., 184: 101-109, 2000

Peaslee D. E. and D. H. Moos, Photosynthesis in K and Mg deficient Maize (Zea mays L.) leaves. Soil Sci. Soc. Am. Proc., 30: 220-223, 1966

Plaut, Z. and C. M. Grieve, Photosynthesis of salt stressed maize as influenced by Ca: Na ratios in the nutrient solution. Plant. Soil., 105: 283 286, 1988

Qadir, M., A. Ghafoor and G. Murtaza, Amelioration strategies for saline soils: a review. Land Degrad. Develop., 11: 501-521, 2000

Qadir, M., S. Schubert, A. Ghafoor and G. Murtaza, Amelioration of sodic soils: a review. Land Degrad. Develop., 12: 357-386, 2001

Rozema, J., H. Gude, F. Bijl and H. Wesselman, Sodium concentration in xylem sap in relation to ion exclusion, accumulation and secretion in halophytes. Acta Bot. Neerl., 30: 309-311, 1981

Sokal, R. R., and F. J. Rohlf, Biometry: The Principles and Practice of Statistics in Biological Research. Second Edition. W. H. Freeman, San Francisco, California, 1981 